\title{
Heterosexual transmission of human immunodeficiency virus infection - Strategies for prevention
}

Brian Conway, MD, D William Cameron, MD, Francis A Plummer, MD, AlLAN R Ronald, MD

B Conway, w Cameron, FA Plummer, AR Ronald. Heterosexual transmission of human immunodeficiency virus infection - Strategies for prevention. Can J Infect Dis 1991;2(1):30-36. In Canada, over 90\% of the acquired immune deficiency syndrome cases diagnosed so far have been acquired sexually, with an increasing proportion made up of heterosexual contacts of high risk individuals. In multiple studies, the transmission rate among steady heterosexual partners of infected individuals has been variable. It is likely that complex biological and epidemiological interactions exist between human immunodeficiency virus (HIV) and sexually transmitted diseases with respect to transmission and disease. Other important determinants in transmission of infection may relate to the virus itself. The importance of sexual practices other than vaginal intercourse (such as anal intercourse) in the heterosexual transmission of HIV has not been well studied. The major approach to the control of HIV-associated disease remains the control of primary infection. Sexual practices which are the major epidemiological determinants of HIV transmission can be successfully modified by appropriate educational interventions. The promotion of condom use must form a special part of these interventions. Results of ongoing trials should be available prior to the formulation of recommendations for the use of spermicides. Targeted education programs may allow us to make better use of our resources in a more efficient way. In Canada, groups that could be reached by such programs include: prostitutes and their clients; men and women attending sexually transmitted disease clinics; sexually active women attending family planning clinics; and children and adolescents who are becoming sexually active.

Key Words: Condoms, Education, Heterosexual transmission, Spermicides

\section{La transmission hétérosexuelle du virus d'immunodéficience acquise: Stratégies préventives}

RESUME: Au Canada, plus de $90 \%$ des cas de syndrome d'immunodéficience acquise diagnostiqués jusqu'ici ont été transmis sexuellement et un pourcentage grandissant de cas sont attribuables à des contacts hétérosexuels avec des personnes à haut risque. Des études multiples révèlent que le taux de transmission parmi les partenaires hétérosexuels stables des sujets contaminés est varié. Il est probable que des interactions biologiques et épidémiologiques complexes existent entre le virus d'immunodéficience humaine et les maladies transmises sexuellement quant à la transmission et à la maladie. D'autres déterminants importants de la

Departments of Medicine and Medical Microbiology. University of Manitoba, Winnipeg, Manitoba; and Division of Infectious Diseases, Ottawa General Hospital, Ottawa, Ontario

Correspondence and reprints: Dr Brian Conway. Ottawa General Hospital, 501 Smyth Road, Ottawa. Ontario K1H 8 L6. Telephone (613) 737-8165 


\begin{abstract}
transmission de l'infection seraient liés au virus lui-même. L'importance des pratiques sexuelles autres que les rapports par voie vaginale (par voie anale, par exemple) dans la transmission hétérosexuelle du virus n'a pas été bien étudiée. La stratégie majeure dans la prévention des maladies associées au VIH reste le contrôle de l'infection primaire. Les interventions éducatives appropriées peuvent parvenir à modifier les pratiques sexuelles qui constituent les déterminants épidémiologiques majeurs de la transmission du virus d'immunodéficience humaine. La promotion des condoms doit figurer tout spécialement parmi ces interventions. Les résultats d'études actuellement en cours devraient être connus avant que l'on recommande l'usage des spermicides. Certains programmes éducatifs cibles nous permettront peut-être de faire un usage plus judicieux de nos ressources. Au Canada, les groupes à rejoindre dans ce cadre seraient: les prostituées et leurs clients, les hommes et femmes qui fréquentent les cliniques traitant les maladies vénériennes, ainsi que les enfants et adolescents qui commencent à mener une vie sexuelle active.
\end{abstract}

U P TO MAY 7, 1990, THE FEDERAL CENTRE FOR AIDS had received reports of 3818 cases meeting the surveillance case definition for acquired immune deficiency syndrome (AIDS), and estimated that there would be a cumulative total of 7000 cases by 1992 (1). As projected cases reflect persons now infected, any slowing in the rate of spread of the human immunodeficiency virus (HIV) will have no effect on these estimates. However, as many as 4000 Canadians will acquire HIV in 1990, with about 20\% of these individuals going on to AIDS by 1995.

In Canada, over $90 \%$ of the AIDS cases diagnosed so far have been acquired sexually, with an increasing proportion made up of heterosexual contacts of high risk individuals (1). These reported cases reflect the epidemiology of HIV five to 10 years ago. The current seroprevalence in heterosexuals is a better predictor of future disease spread. In a recent study of HIV infection in Quebec women giving birth to live infants, one in 1638 women were found to be seropositive (2), with one in 216 being seropositive in certain areas of Montreal. In this review, the available information on heterosexual transmission of HIV will be outlined, and control strategies which may be included in Canadian public health programs discussed.

\section{HETEROSEXUAL TRANSMISSION}

In 1982, AIDS-defining opportunistic infections were noted in five previously healthy women (3). Conclusive evidence of heterosexual transmissibility of HIV was presented in 1983 (4). In a seroepidemiological study of female prostitutes in Kenya, HIV infection has been associated with sexual contact with infected migrant men from central Africa (5). Globally, heterosexual transmission is the major route of disease spread. It has rapidly become significant in North America. The proportion of women with AIDS acquiring the infection through heterosexual contact with an in- fected individual increased from 12 to $25 \%$ between 1982 and 1987 (6).

The current low prevalence of AIDS in the heterosexual population has led to the commonly held belief that the risk of heterosexual transmission is very low. The risk of infection following intercourse with a seropositive individual has been estimated at $0.2 \%$ (7). However, in a study of men in Nairobi exposed to prostitutes, $85 \%$ of whom were infected, $8 \%$ seroconverted following a single exposure (8). In Australia, four of eight women seroconverted following insemination from an infected sperm donor (9). In multiple studies, the transmission rate among steady heterosexual partners of infected individuals has been variable, ranging from 0 to $60 \%(10,11)$. This heterogeneity of transmission likely relates to the action of a variety of cofactors, such as the other sexually transmitted diseases identified in the Kenyan study (8).

Specific risk factors for male-to-female transmission include ulcerative (8) and nonulcerative (12) sexually transmitted diseases, cervical ectopy (13) and oral contraceptives (14). Repeated exposure is also important $(5,15)$. In one comparative study, seropositive women were 4.6 times more likely to have had more than 100 episodes of unprotected vaginal intercourse with their infected partners (16). The risk of infection in females following 500 unprotected sexual encounters with a seropositive partner was estimated to be $67 \%$ (7).

As the virus has been isolated from vaginal secretions (17), uterine cervix (18) and genital ulcers (19), it is likely that female-to-male transmission is also important with respect to disease spread. However, it appears to be less efficient than male-to-female transmission. In a recent study, 41 male sexual partners of $38 \mathrm{HIV}$-infected women were studied (20). Only one male partner was infected. The male-to-female transmission rate for 219 couples recruited in the same way over the same period was $20 \%$. Whether this large 
difference can be attributed entirely to biological mechanisms of transmission, to sample specific phenomena, or to other factors, remains to be determined.

Genital ulcer disease caused by Haemophilus ducreyi appears to be a biological cofactor for heterosexual transmission. In one study, men showed a relative risk of 4.7 for HIV seroconversion in the presence of active ulcers in women (8). Similarly, in a study of women who acquired genital ulcer disease from a population of men with an HIV seroprevalence of $25 \%$, it is estimated that $45 \%$ became infected with HIV (21). The association between serological markers for syphilis and HIV seropositivity has been repeatedly demonstrated (22). Furthermore, an association between genital herpes and HIV infection has been demonstrated (23). It remains unclear whether this association reflects concurrent or sequential exposure to the pathogens. The significance of nonulcerative sexually transmitted diseases is less well understood. In a retrospective study, it was reported that chlamydial cervicitis had occurred more frequently in a group of Kenyan prostitutes prior to HIV seroconversion (24). Interestingly, a study of 35 heterosexual couples with one HIV-infected partner revealed a gradation in the HIV seroconversion rate as a function of ulcerative, nonulcerative or no sexually transmitted disease in either partner (12). In the presence of sexually transmitted diseases, the absence of circumcision in men may also be a cofactor for HIV transmission, with a relative risk of seven in one study (8).

It is likely that complex, bidirectional biological and epidemiological interactions exist between HIV and sexually transmitted diseases with respect to transmission and disease. Susceptibility to HIV infection, as well as the ability to transmit this infection, are both increased in the presence of sexually transmitted diseases, most notably ulcerative sexually transmitted diseases. This leads to an increased incidence and prevalence of HIV infection, and subsequent immune disease, which may then give rise to an increased prevalence of sexually transmitted diseases, as a result of more persistent genital lesions in an immunocompromised host. These interactions may serve to amplify the prevalence of HIV in a network of sexual contacts, and may account for the explosive epidemic of HIV observed in some risk groups.

Other important determinants in transmission of infection may relate to the virus itself. There are significant differences in infectivity among different viral strains (25). Other studies suggest that a more advanced clinical stage of disease and a low concentration of CD4+ lymphocytes enhance transmissibility $(26,27)$. These observations may relate to an increasing inability of the host to regulate viral replication. In fact, one early study showed HIV antigenemia in $86 \%$ of AIDS patients compared to $19 \%$ of seropositive individuals with less advanced disease (28). Recent work using quantitative culture techniques has clearly shown an association between viral load and stage of disease (29).

The importance of sexual practices other than vaginal intercourse in the heterosexual transmission of HIV has not been well studied. The frequency of anal sex among heterosexuals has likely been underestimated (30). In a survey of 3905 university students in Puerto Rico, 31\% of sexually active women admitted to practising anal sex (31). In a study of female partners of infected men, 18 of 33 engaging in receptive anal intercourse were found to be infected, compared with eight of 42 others (32). A more recent study confirms the significance of unprotected anal intercourse in heterosexual HIV transmission (33). The risk of transmission by oral-genital contact is uncertain. In one study, 11 of 26 women engaging in repeated oral sex with infected partners became infected, compared with one of 19 others (10). Other studies have failed to confirm these findings (16).

\section{CHANGING THE COURSE OF THE EPIDEMIC}

Given the limited therapeutic options with respect to HIV, the major approach to disease control remains the control of primary infection. Sexual practices are the major epidemiological determinants of sexual transmission of HIV. These practices can be successfully modified by appropriate educational interventions.

Sexually active individuals must be made aware that they place themselves and their partners at risk for all sexually transmitted diseases, including HIV. The safest practices include activities in which no semen, vaginal fluid or blood is exchanged between partners. The intact skin and oral mucosa are resistant to virus passage (34). Practices such as kissing, hugging, caressing and genital manipulation are thus extremely safe and may be promoted as such. Information regarding oral-genital contact is inconclusive. It is likely that most studies undertaken to address this question were influenced by confounding or bias. At present, this should be regarded as an activity with a small, but definite, risk.

Other forms of sexual behaviour carry a significantly higher risk. Although the current risk of becoming infected with HIV following a single sexual exposure is low, it must be emphasized 
that there are many reports of such single exposures leading to infection. In education programs, special emphasis should be placed on avoidance of sexual contact with partners at risk themselves, including intravenous drug users and prostitutes.

Studies have shown that the most important determinant of the risk of a sexual encounter for HIV transmission is the likelihood that one's partner exhibits high risk behaviour (7). Infection rates exceeding $5 \%$ have been detected in a study of Toronto prostitutes (35), and are likely much higher now. Individuals with active sexually transmitted diseases, particularly ulcerative sexually transmitted diseases, should be considered high risk sexual contacts.

\section{CONDOMS AND SPERMICIDES -} A SPECIAL PART OF THE MESSAGE

Latex condoms have been shown to be effective barriers to HIV (36). In vitro experiments have confirmed that latex condoms are impermeable to retroviruses (37). Further clinical studies have shown an association between condom use and reduced transmission of HIV. With regular use, one in 10 partners of infected individuals seroconverted, compared with 12 of 14 others (10). In an ongoing European study of 100 HIV-discordant couples, no seroconversions occurred in 48 cases in which condoms were used systematically, compared to six of 52 in couples not using them on a constant basis (38). These data have been confirmed by other groups (33). In fact, one study has shown a gradation in HIV seroconversion rates when comparing discordant couples who never use condoms with those who use condoms only on occasion (27).

It is reasonable to assume that widespread use of condoms will slow the sexual transmission of HIV infection. Condoms should be made readily available to certain groups, such as prostitutes. Counselling must also be available to make their proper use widely known. This counselling should emphasize that, as with their use for pregnancy prevention, condoms can be expected to fail. Some sources have suggested that the failure rate may reach $17 \%$ (10). The mechanical failure rate with anal intercourse is likely to be significantly higher than with vaginal intercourse.

In vitro experiments have shown that HIV is inactivated by exposure to $0.05 \%$ nonoxynol-9 for $60 \mathrm{~s}$. This compound is present in much higher concentrations in many spermicides (39). Other groups have reported similar findings (40). A study of the protection offered by a contraceptive vaginal sponge containing $1 \mathrm{~g}$ of nonoxynol-9 has been conducted in Africa (41). No reduction in HIV transmission was observed. A recent Canadian study of Vancouver prostitutes suggests that nonoxynol-9 may cause genital inflammation and irritation and may enhance HIV transmission (42). Results of controlled clinical trials should be available prior to the formulation of any recommendations for the use of nonoxynol-9 with condoms or vaginal contraceptives as barrier prophylaxis against HIV.

The promotion of widespread condom use with or without spermicides cannot, however, be considered an end in itself. Despite efficacy of condom use in protecting African prostitutes from sexually transmitted diseases and HIV infection, the prevalence of ulcerative sexually transmitted diseases is unchanged (unpublished data). In the setting of HIV infection, the increased virulence of genital ulcer disease pathogens may overcome the protective benefit of condom use. As discussed previously, this may in turn serve to increase the transmission of HIV. Clearly, a more comprehensive approach is needed to limit the spread of all sexually transmitted diseases.

\section{DELIVERING THE MESSAGE}

The pressing need to prevent HIV transmission, and to do so effectively within certain budgetary constraints, makes more targeted intervention essential (43). Targeting of groups is also more effective, as it makes it easier to deliver appropriate health education messages in relevant language using well liked, trusted or respected sources. Such messages are more likely to be understood and assimilated (44).

Certain groups of individuals can be identified as being at particular risk of HIV infection. In Canada, these include: prostitutes and their clients; men and women attending sexually transmitted disease clinics; sexually active women attending family planning clinics; and children and adolescents who are becoming sexually active. This list is not exhaustive, but it can help in the development of more targeted educational strategies in addition to the broader education and intervention programs already in place.

The single most important risk factor for HIV transmission in prostitutes in developed countries is intravenous drug use $(45,46)$. While prostitutes may tend to use condoms consistently when having sex with clients, they do not tend to use them as frequently with lovers and husbands (46). It is therefore quite clear that prostitutes who also use drugs must be targeted to encourage enrollment in needle exchange programs and for educational programs aimed at reducing needle sharing and drug use. The use of condoms at all times, especially with nonpaying partners, must also be 
emphasized. It is of particular note that drugusing prostitutes tend to use condoms more erratically (43). Proper education in these groups must be ensured.

Individuals attending sexually transmitted disease clinics can be readily accessed and targeted for preventive activity to encourage reduction in number of sexual partners and early consultation for sexually transmitted disease treatment and condom use (43). It would appear that current general education programs have been moderately effective in disseminating correct information about HIV, as measured by a questionnaire administered to individuals attending sexually transmitted disease clinics (47). Despite this knowledge, less than $50 \%$ use condoms regularly $(48,49)$. One study of direct intervention in sexually transmitted disease clinics to promote safer sex and condom use reports a 50\% reduction in sexually transmitted disease reinfections (50). This approach may thus be feasible and help reduce the incidence of HIV infection.

Insofar as all sexually active women may be at risk of becoming infected with HIV from a single unprotected sexual act with an infected partner, family planning counsellors may wish to discuss condom use in addition to other contraceptive methods (43). Careful selection of sexual partners should also be emphasized. In a survey of over 16,000 women attending such a clinic, $67 \%$ never used condoms with their regular partners, while $72 \%$ never used them with casual partners (51). Interventions should emphasize consistency in condom use as well as partner selection.

Finally, effective programs for AIDS education of children and adolescents must be set up. In young people, sexual behaviour and practices are not yet firmly established. There is a unique opportunity to influence the decision to become sexually active and to emphasize the importance of partner selection and condom use.

In general, it would appear that adolescents are quite well informed about HIV. In a Massachusetts

\section{REFERENCES}

1. Federal Centre for AIDS. AIDS surveillance in Canada. CDWR 1990;16:93-5.

2. Hankins CA, Laberge C, Lapointe N, et al. HIV infection among Quebec women giving birth to live infants. Can Med Assoc J 1990; 143:885-93.

3. Masur H, Michelis MA, Wormser GP, et al. Opportunistic infection in previously healthy women: Initial manifestations of a communityacquired cellular immunodeficiency. Ann Intern Med 1982;97:533-9.

4. Harris C, Butkus-Small C, Klein RS, et al. Immunodeficiency in female sexual partners of men with the acquired immunodeficiency survey of 16- to 19-year-olds performed in 1989, over $99 \%$ knew the virus could be transmitted during heterosexual intercourse (52). Almost half worried some or a great deal about getting AIDS. However, only 35\% always used condoms during intercourse. In a similar survey done in Quebec, it appeared that many adolescents did not perceive the need to use condoms if the girl was using oral contraceptives (53). Education programs must emphasize the necessity of using condoms, even when the female partner is taking oral contraceptives.

A number of worthwhile initiatives have already taken place in Canada. In the Montreal area, high school students were involved in the development of education programs for AIDS prevention in conjunction with World AIDS Day in 1989 (54). Over 4000 students were reached in this project. A longer term program using peer educators who have taken a week-long intensive training program prior to visiting area high schools has also worked quite well (55). This type of program could be adapted to reach out-of-school youth, who constitute the highest risk group for sexually transmitted disease and HIV transmission (56), and have yet to be adequately reached. As presenters with AIDS have been shown to have the most impact on sexual behaviour (particularly condom use) in some programs (57), such presenters should definitely be included in Canadian programs, particularly those aimed at out-ofschool youth. Quebec's health and social services ministry is currently initiating a province-wide campaign to reduce the spread of AIDS and other sexually transmitted diseases (58). Unlike an earlier campaign, it promotes condom use as part of healthy sexuality. Television advertisements will talk frankly about condom use, supported by advertisements on buses and in magazines and newspapers targeted at youth. Speaking tours of Quebec's junior colleges and free condom distribution are also planned. Programs of this type should be promoted throughout Canada.

syndrome. N Engl J Med 1983;308:1181-4.

5. Kreiss JK, Koech D, Plummer FA, et al. AIDS virus infection in Nairobi prostitutes: Spread of the epidemic to East Africa. N Engl J Med 1986;314:414-8.

6. Guinan ME, Hardy A. Epidemiology of AIDS in women in the United States. JAMA 1987;257:2039-42.

7. Hearst N, Hulley SB. Preventing the heterosexual spread of AIDS. Are we giving our patients the best advice? JAMA 1988;259:2428-32.

8. Cameron DW, Simonsen JN, D’Costa LJ, et al. Female to male transmission of human immunodeficiency virus type 1: Risk factors for 
seroconversion in men. Lancet 1989;ii:403-7.

9. Stewart GJ, Tyler JPP, Cuningham AL, et al. Transmission of human T-cell lymphotropic virus type III (HTLV-III) by artificial insemination by donor. Lancet 1985;i:581-4.

10. Fischl MA, Dickinson GM, Scott GM, Klimas M, Fletcher MA, Parks W. Evaluation of heterosexual partners, children and household contacts of adults with AIDS. JAMA 1987;257:640-4.

11. Redfield RR, Markham PD, Salahuddin SZ, et al. Frequent transmission of HTLV-III among spouses of patients with AIDS-related complex and AIDS. JAMA 1985;253:1571-3.

12. Cameron DW, Kosseim ML, Oduor D, et al. Serologic concordance and incidence of HIV in regular sexual partners in Nairobi, Kenya. Fifth International Conference on AIDS. Montreal: International Development Research Centre, 1989:TAP.91. (Abst)

13. Moss GB, D'Costa LJ, Ndinya-Achola JO, et al. Cervical ectopy and lack of male circumcision as risk factors for heterosexual transmission of HIV in stable sexual partnership in Kenya. Sixth International Conference on AIDS, San Francisco, 1990:ThC570. (Abst)

14. Mati J, Maggwa A, Chewe D, et al. Contraceptive use and HIV infection among women attending family planning clinics in Nairobi, Kenya. Sixth International Conference on AIDS, San Francisco. 1990:ThC99. (Abst)

15. Padian NS, Shiboski SC, Jewell NP. The effect of number of exposures on the risk of heterosexual HIV transmission. J Infect Dis 1990;161:883-7.

16. Padian N, Marquis L, Francis DP, et al. Male-to-female transmission of human immunodeficiency virus. JAMA 1987;258:788-90.

17. Wofsky CB, Cohen JB, Hauer LB, et al. Isolation of AIDS-associated retrovirus from genital secretions of women with antibodies to the virus. Lancet 1986;i:527-9.

18. Pomerantz RJ, de la Monte SM, Donegan SP, et al. Human immunodeficiency virus (HIV) infection of the uterine cervix. Ann Intern Med 1988; 108:321-7.

19. Plummer FA, Wainberg MA, Plourde P, et al. Detection of human immunodeficiency virus type 1 (HIV-1) in genital ulcer exudate of HIV-1-infected men by culture and gene amplification. J Infect Dis 1990;161:810-1.

20. Padian N, Shiboski S, Jewell N. The relative efficiency of female-to-male HIV sexual transmission. Sixth International Conference on AIDS, San Francisco, 1990:ThC101. (Abst)

21. Plourde P, Plummer FA, Pépin J, et al. Incidence of HIV-1 seroconversion in women with genital ulcers. Sixth International Conference on AIDS, San Francisco, 1990:ThC571. (Abst)

22. Quinn TC, Glasser D, Cannon RO. Human immunodeficiency virus infection among patients attending clinics for sexually transmitted diseases. N Engl J Med 1988;318:197-203.

23. Holmberg SD, Stewart JA, Gerber AR, et al. Prior herpes simplex virus type 2 infection as a risk factor for HIV infection. JAMA 1988;259:1048-50.

24. Plummer FA. Cofactors in male-female transmission of HIV. J Infect Dis. (In press)

25. Cheng-Mayer C, Shioda T, Seto D, Levy JA. Physical mapping of replicative and cytopathic properties of HIV-1. Sixth International Conference on AIDS, San Francisco, 1990:ThA68. (Abst)

26. Rehmet S, Staszewski S, V. Wangenheim I, et al. HIV transmission rates and cofactors in heterosexual couples. Sixth International Conference on AIDS, San Francisco, 1990:ThC582. (Abst)

27. Papetti C, Mezzaroma I, D’Offizi JP, et al. High prevalence of HIV heterosexual transmission in one hundred stable couples. Sixth International Conference on AIDS, San Francisco, 1990:FC46. (Abst)

28. Goudsmit J, Paul DA. Circulation of HIV antigen in blood according to stage of infection, risk group, age and geographic origin. Epidemiol Infect 1987;99:701-10.

29. Ho DD, Mougdil T, Alam M. Quantitation of human immunodeficiency virus type 1 in the blood of infected persons. N Engl J Med 1989;321:1621-5.

30. Bolling DR, Voeller B. AIDs and heterosexual anal intercourse. JAMA 1987;258:474.

31. Cunningham I, Rodriguez Sanchez M. AIDS knowledge and sexual behavior among University of Puerto Rico students. Sixth International Conference on AIDS, San Francisco, 1990:ThD774. (Abst)

32. Sion FS, Morais DSC, Rachid De Lacenda MC, et al. The importance of anal intercourse in transmission of HIV to women. Fourth International Conference on AIDS. Stockholm: Swedish Ministry of Health and Social Affairs, 1988:4007. (Abst)

33. Chiodo F, Marinacci G, Costigliola P, Riochi E, Colangeli V. Risk factors in heterosexual transmission of HIV. Sixth International Conference on AIDS, San Francisco, 1990:ThC583. (Abst)

34. Friedland GH, Klein RS. Transmission of the human immunodeficiency virus. N Engl J Med 1987;317:1125-35.

35. Read SE, Cave C, Goldberg E. Sexually transmitted diseases including HIV infection in teenage prostitutes. Fourth International Conference on AIDS. Stockholm: Swedish Ministry of Health and Social Affairs, 1988:4045. (Abst)

36. Voeller B, Potts M. Has the condom any proven value in preventing the transmission of sexually transmitted viral disease - for example acquired immune deficiency syndrome? Br Med J 1985;291:1196.

37. Conant M, Hardy D, Sernatinger J, Spicer D, Levy JA. Condoms prevent transmission of AIDS-associated retrovirus. JAMA 1986;255:1706.

38. DeVincenzi I, Ancelle-Park R. Heterosexual transmission of HIV; follow-up of a European cohort of couples. Sixth International Conference on AIDS, San Francisco, 1990:ThC100. (Abst)

39. Hicks DR, Martin LS, Voeller B, et al. Inactivation of LAV/HTLV-III infected cultures of normal human lymphocytes by nonoxynol-9 in vitro. Lancet 1985;ii:1422-3.

40. Rietmeijer CAM, Krebs JW, Ferino PM, Judson FN. Condoms as physical and chemical barriers against human immunodeficiency virus. JAMA 1988;259:1851-3.

41. Kreiss J, Ruminjo A, Ngugi E, Roberts P, Ndinya-Achola J, Plummer F. Efficacy of 
nonoxynol-9 in preventing HIV transmission. Fifth International Conference on AIDS. Montreal: International Development Research Centre, 1989:MAO.36. (Abst)

42. Rekart ML, Barnett JA, Manzon LM, et al. Nonoxynol-9: Its adverse effects. Sixth International Conference on AIDS, San Francisco, 1990:SC36. (Abst)

43. Gillies P, Carballo M. Adult perception of risk, risk behavior and HIV/AIDS: A focus for intervention and research. AIDS 1990;4:943-57.

44. Longshore D. Reaching population at higher risk of AIDS. AIDS Public Policy J 1988;4:101-5.

45. Rosenberg MJ, Weiner J. Prostitutes and AIDS: A health department policy? Am J Public Health 1989;78:418-23.

46. Thomas RM, Plant MA, Plant MC, Sales DI. Risk of AIDs among workers in the sex industry: Some initial results from a Scottish study. Br Med J 1989;299:148-9.

47. Farr G, Magruder C, Foldesy R, Greenup R, Staab R. Knowledge and awareness of AIDS among patients at a sexually transmitted disease clinic. Sixth International Conference on AIDS, San Francisco, 1990:SC690. (Abst)

48. Weinstock H, Lindan C, Bolan G, et al. Condom use among heterosexuals in a sexually transmitted disease clinic in San Francisco. Sixth International conference on AIDS, San Francisco, 1990:FC727. (Abst)

49. Farr G, Magruder C, Foldesy R, Staab R. Acceptability of condom use among patients at a sexually transmitted disease clinic. Sixth International Conference on AIDS, San Francisco, 1990:FC740. (Abst)

50. Cohen D, Dent C, MacKinnon D. Safer sex education and sexually transmitted disease reinfection. Sixth International Conference on AIDS,
San Francisco, 1990:SC678. (Abst)

51. Aral SO, Soskolne V, Magder LS, Bowen GS. Condom use by women seeking family planning services. Sixth International Conference on AIDS, San Francisco, 1990:FC747. (Abst)

52. Berlin B, Hingson R, Strunin L, Heerin T. Changes in adolescent condom use, knowledge and beliefs about AIDs in Massachusetts. Sixth International Conference on AIDS, San Francisco, 1990:SC576. (Abst)

53. Otis J, Godin G, Lambert J, Pronovost R.

Adolescents and condom use: The difference between contraception and sexually transmitted disease-AIDS prevention. Sixth International Conference on AIDS, San Francisco, 1990:SC44. (Abst)

54. Bastien R, Longpré D, Thomas R, Otis J, Provencher S, Lonergan G. Action oriented and participant observation strategies used to enhance participation of students in the prevention of AIDS. Sixth International Conference on AIDS, San Francisco, 1990:4047. (Abst)

55. Caron F, Newell M, Otis J, Lambert J. The AIDS traveling road show: Evaluation of a peer education program on AIDS awareness and prevention in the high school. Sixth International Conference on AIDS, San Francisco, 1990:3083. (Abst)

56. MacDonald NE, Bowie WR, Fisher W, et al. Street kids in Canada: Sex and sexually transmitted diseases (STD: What they know and do). Clin Invest Med 1990;13:B19.

57. Evans NL, Fetro J. HIV education program involving presentors with AIDS demonstrates significant impact on adolescents. Sixth International Conference on AIDS, San Francisco, 1990:ThD850. (Abst)

58. Charbonneau L. Quebec now crazy for condoms. Med Post 1990;26(39):2. 


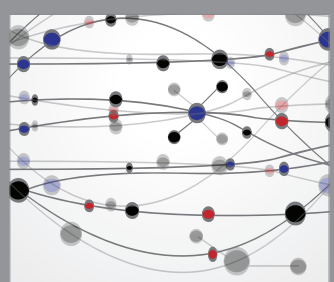

The Scientific World Journal
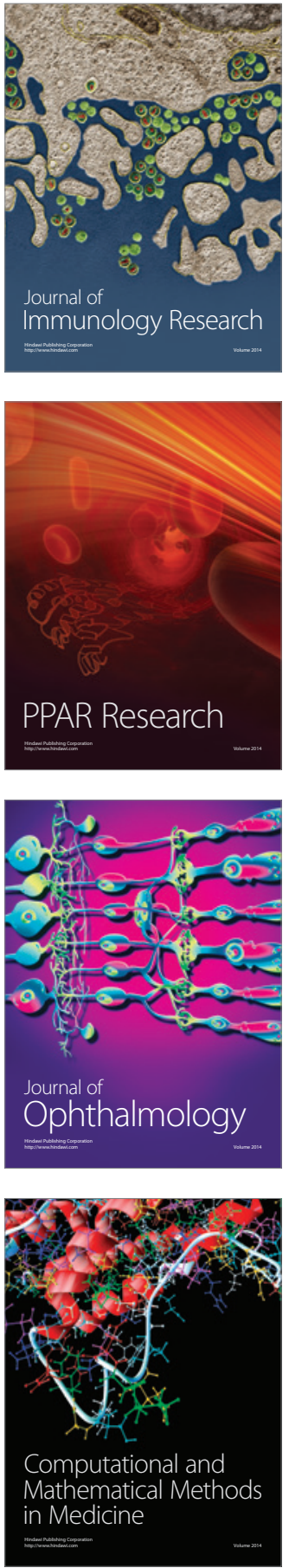

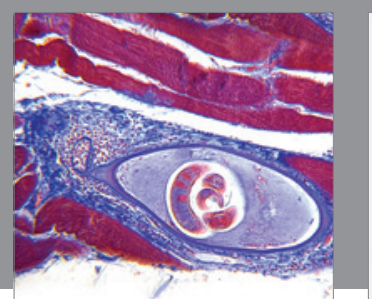

Gastroenterology Research and Practice

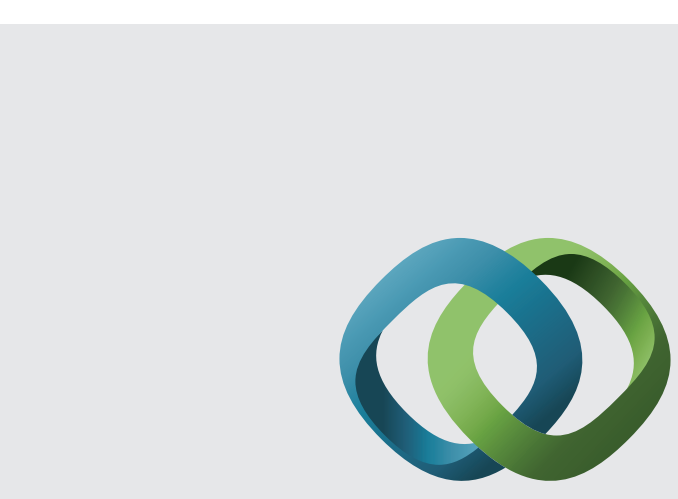

\section{Hindawi}

Submit your manuscripts at

http://www.hindawi.com
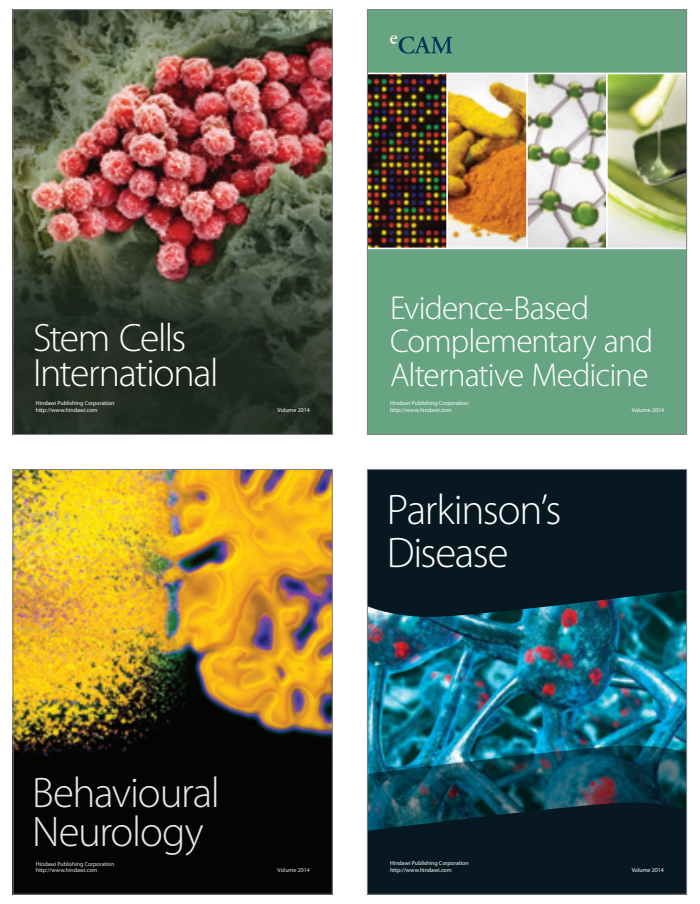
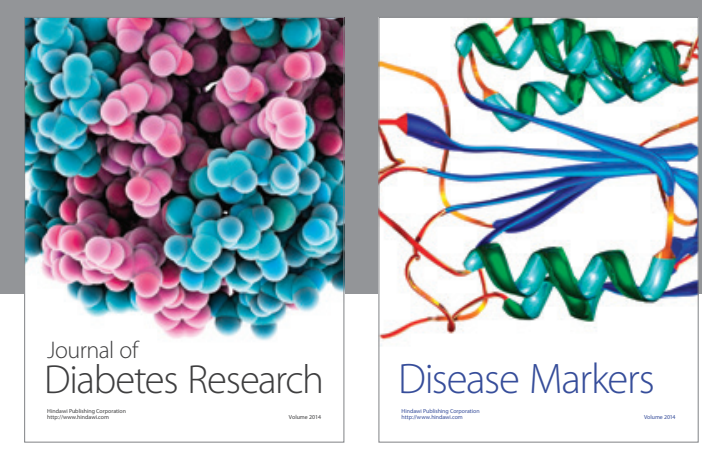

Disease Markers
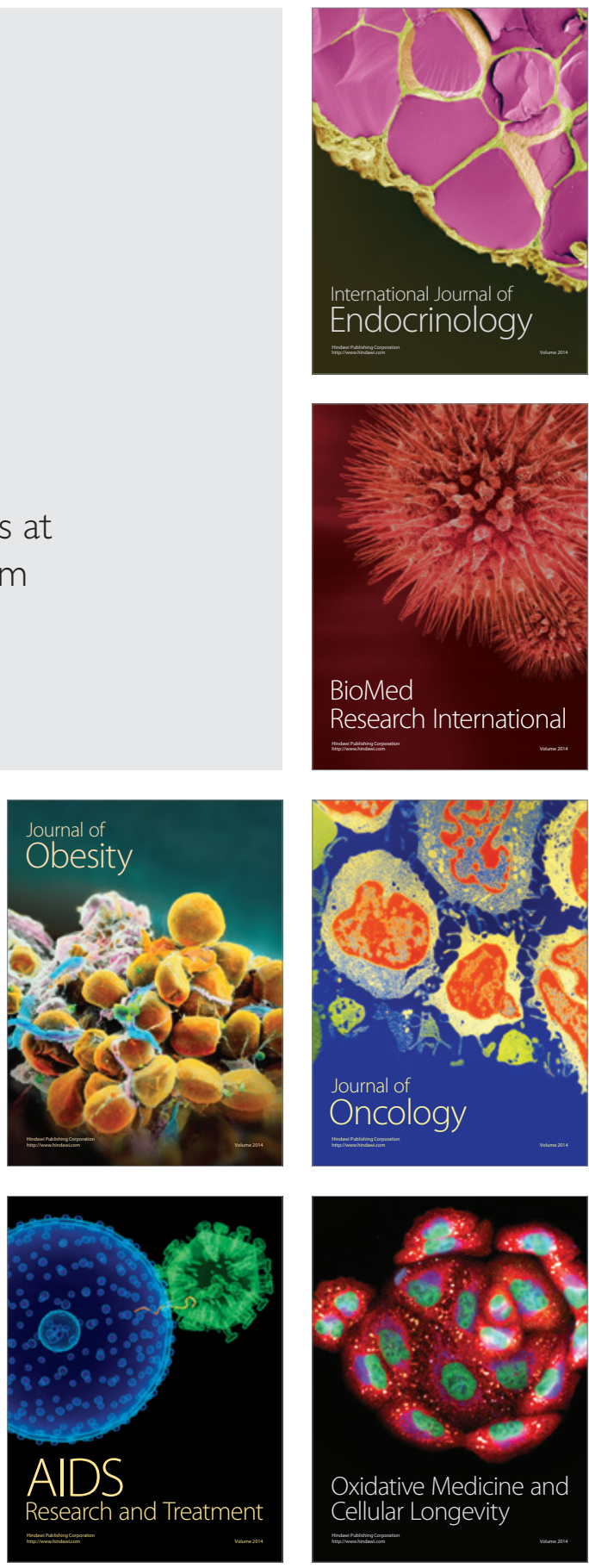